\title{
A MAGYAR SPORTPOLITIKA LEGFŐBB JELLEMZŐI, INTÉZKEDÉSEI 1945- TÖL KEZDŐDŐEN A RENDSZERVÁLTÁSIG ÉS NAPJAINKIG, KÜLÖNÖS TEKINTETTEL A LABDARÚGÁS SPORTÁGÁRA
}

\section{Szerzők:}

\section{Rábai Dávid}

Debreceni Egyetem Gyermeknevelési és

Gyógypedagógiai Kar (Magyarország)

Első szerző e-mail címe:

david.rabai67@gmail.com

\section{Lektorok:}

Prof. Dr. Kozma Tamás, PhD

Debreceni Egyetem (Magyarország)

Dr. Fenyő Imre, PhD

Debreceni Egyetem (Magyarország)

Rábai Dávid (2018): A magyar sportpolitika legfőbb jellemzői, intézkedései 1945-től kezdődően a rendszerváltásig és napjainkig, különös tekintettel a labdarúgás sportágára. Különleges Bánásmód, IV. évf. 2018/1. szám, 19-33. DOI 10.18458/KB.2018.1.19

\begin{abstract}
Absztrakt
Jelen elméleti jellegü tanulmányunk célkitüzése, hogy felderitse és bemutassa a magyar sporton és a labdarúgáson belül végbemenö sportpolitikai intézkedéseket és piacositási folyamatokat, amely a neoliberális gondolkodás egyik eredményeképpen indult be és ment végbe hazánkban a rendszerváltástól kezdödöen. A dolgozatunkban ezeket a lehetséges kiváltó okokat vesszük górcsö alá az ebben a témában született kutatási eredmények és tanulmányok alapján. Célunk, hogy 1945-töl kezdödően keressük azokat a kiváltó eseményeket, amelyek a sportpolitikai folyamatok változásaihoz, esetleges paradigmaváltásához vezethettek. Célunk még, hogy kiemelten a labdarúgás sportágát sportpolitikai vizsgálódás alá vessük és kapcsolódási pontokat keressünk a labdarúgó akadémiákkal összefüggésben.

A tanulmányunk több fejezetböl épül fel. Az elsö fö részben a magyar sport helyzetét tekintettük át a sportpolitikai változások tükrében 1945-töl kezdödöen egészen a rendszerváltozásig, illetve az azt követö évekig. A második fö fejezetben a labdarúgással kapcsolatos legföbb sportpolitikai intézkedéseket és az ezzel járó változásokat tekintettük át ugyanezen korszakot vizsgálva. Ennek a fejezetnek a harmadik alegységében, külön alfejezetben tárgyaltuk a labdarúgó akadémiákkal kapcsolatos legföbb politikai változásokat.

Kutatásunk eredményeképpen kiderült, hogy a szocialista rendszert befejezö rendszerváltás jelensége markáns politikai változásokat hozott mind a sport, mind pedig szükebb értelemben a labdarúgás sportágán belül. A legföbb változásként a piacosodási folyamat emelhetö ki, amellyel hazánk labdarúgása a nyugati minták követésének irányába indult. A labdarúgó akadémiák széleskörü elterjedése politikai döntések eredményeként határozható meg,
\end{abstract}


azonban hiába müködnek közel már 17 éve hazánkban, mégsem tudják határozottan igazolni a létjogosultságukat.

Kulcsszavak: szocializmus, rendszerváltozás, politika, labdarúgó akadémiák

Diszciplina: sportpolitika, sportszociológia, sportpedagógia

\begin{abstract}
The aim of our present theoretical study is to explore and present the sport policy measures and marketization processes within the Hungarian sport and football that started and has been going on as a result of neoliberal thinking in our country since the change of the political regime (1989/90). In our paper, we are looking at these potential causes based on the research findings and studies that have emerged in this topic. Our goal is to find the events that triggered changes from the 1945 onwards, which could have led to changes in the sport policy processes and possible paradigm shift. Our goal is to focus on the sport of football in sports politics and to look for links in connection with the football academies.

Our study has several chapters. In the first major part, we review the situation of the Hungarian sport in the light of sport policy changes from 1945 until the change of the political regime and the following years. In the second major chapter, we survey the major sports policy measures and related changes in football during the same era. In the third subsection of this chapter, we discussed the major political changes in football academies in a separate subchapter.

As a result of our research, it has turned out that the change of the political regime brought up significant political changes both in sports, and properly in the field of football. The major change could be the marketization process with which our country's football started to follow western patterns. The widespread dissemination of football academies can be explained with a set of political decisions. Even though they have been working for almost 17 years in Hungary they can not fully justify their legitimacy.
\end{abstract}

Keywords: socialism, political tranformation, policy, football academies

Disciplines: sports policy, sport sociology, sport pedagogy

\title{
Bevezetés
}

Ami bizonyos, hogy a futball rendkívül demokratikus játék volt a régi időkben: amikor a szurkolók a stadionba jutottak, gyakorlatilag megszüntek azok az elvi kérdések, miszerint ki mivel foglalkozik, milyen körülmények között él, hol éli a mindennapjait. Egy-egy mérkőzéskor az imádott csapatuk góljainál egymás nyakába ugorva ünnepeltek, nem törődve semmilyen esetleges hierarchisztikus okokból fakadó elöítélettel. Krausz (2008) szerint azonban mára ez már nem több egy pozitív töltetủ nosztalgikus élménynél: szerinte ugyanis a futballt totálisan ellenőrzés alá helyező tőkerendszer kiterjesztette a futballipart az újrakapitalizálás útjára terelve, megszüntetve ezzel a régebbi korokra jellemző, leggyakrabban a stadionokban tapasztalható különös egységet a szurkolótársadalom között (Krausz, 2008). Ennek a részeként a szerző több lényegi változást is hoz példaként: szerinte napjainkban a 
stadionokban a pénz alapján strukturálódnak az emberek, éppen ezért a legszegényebbek egyszerüen alig jutnak be egy-egy mérkőzésre elsősorban a horribilis jegyárak miatt. Általában a leggazdagabbak kerülnek a legjobb helyekre, elzárják a többiektől és különböző privilégiumokkal (étel, ital, jobb ülőhely, stb.) illetik meg őket. Nem beszélve a stadionokba érkező vendégszurkolók ,fogadtatásáról” sem, akiket szinte kirekesztenek a többiektől, őrzött gettót létrehozva ezzel, melynek eredőjeként a rasszizmus és a tömeges erőszak kiszorítását, megfékezését lehet említeni legfőbb okként (Krausz, 2008).

Ami azonban kijelenthető, hogy a labdarúgásban megjelenő üzleti elemek két „siker” fogalmat alkottak, amely által kétféle sikermércét tudunk megkülönböztetni egymástól (András, 2004). Az egyik „sikerféle” a sportspecifikus, amely egy adott versenysorozatban elérhető sportszakmai sikert jelenti, a másik „sikerféle” pedig a gazdasági siker, amely leírható eredménykategóriával és számvitelileg elszámolható (András, 2004).

Érdekes kérdésként jelenik meg a tehetséggondozás kérdésköre is a labdarúgás sportágán és a sportpolitikán belül (Orosz \& Mező, 2015). Köztudott, hogy minden sportág jövőjét éppen a magas szintü utánpótlás-nevelés hivatott elöidézni, ezért is elengedhetetlen kérdés az, hogy milyen szintü az adott sportág utánpótlásnevelö képzése, illetve milyen infrastruktúra van jelen egy-egy ilyen bázisban. Vincze (2008) szerint az 1980-as években végbemenő politikai és gazdasági változások az utánpótlás-nevelésre és azon belül a labdarúgó-tehetséggondozásra egyaránt rendkívül negatív hatással voltak elsősorban az abban az időben jellemző pénzelvonások, illetve a fejlödési és fejlesztési lehetőségek erőteljes lecsökkentése miatt. A labdarúgó akadémiák kapcsán létrejött korábbi (Rábai, 2016) eredményekböl tudhatjuk, hogy a vizsgált labdarúgó akadémiák különböző infrastrukturális háttérrel rendelkeznek, amely nem biztos, hogy az elitképzésre enged elsősorban következtetni (Rábai, 2016). Mindezt azonban érdemes lesz majd nagyobb mintán is megvizsgálni a jövőben, amely azonban nem a jelen tanulmány feladataként jelenik meg.

A bevezetést követő első fő részben áttekintésre kerülnek a magyar sportpolitikára jellemző legfőbb változások 1945 utáni évektől kezdődően egészen a rendszerváltozásig és az azutáni időkre terjedően. Láthatjuk majd, hogy melyek voltak azok a lényegi változások, események, amelyek megalapozták a rendszerváltás előtti és utáni sportpolitika fontosabb elemeit.

\section{A magyar sport és politika kapcsolata az 1945 utáni években}

A II. világháborút követően a szocialista sportvezetés több területen is szakítani akart az addig leginkább militaristaként és hazafiasként ismert sportpolitikával. Az volt a legfőbb céljuk, hogy a széles tömegek sportját hangsúlyozzák (Dóczi, 2011). Emellett a rendszernek legitimációra is szüksége volt, amelyet viszont az élsport segítségével igyekeztek elérni az akkori sportvezetők (Újhegyi, 1949; Dóczi, 2011). Az 50'-es, 60'-as évekre jellemző volt, hogy rengeteg sportegyesület alakult meg és mivel a politika ezeket szervezetileg nem tudta államosítani, így az egyes ágazatokat, állami vállalatokat kötelezte a megalakuló klubok finanszírozására, mindezt pedig szovjet mintára alapozva. Ennek a lényegi következményeként jelentkezett, hogy a politikai vezetés korlátlan befolyást szerzett az elvileg civil szervezetként müködő sportszervezetek döntéshozatalában (Dóczi, 2011). Az 1950-es évek jellemzője volt, hogy az új rendszerként müködő kommunista rezsim igyekezett átfogalmazni a különböző sportegyesületekhez köthető társadalmi identitásokat. Erre releváns példaként jelentkezett, hogy átszervezés és átnevezés alá kerültek bizonyos labdarúgóklubok is. Így jöhetett létre az, hogy a futballpályákon a különböző szakmák vagy szakszervezetek csapatai estek egymásnak, mint például a bányászok, vasutasok vagy éppen a honvédség, rendőrség csapatai (Hadas és Karády, 1995; Dóczi, 2011). 1956 után némi enyhülés volt 
megfigyelhetö, amelynek ékes példájaként jelentkezett, hogy a sportegyesületek visszakapták a korábban elvett jelvényeik és klubszíneik használati, müködési jogait (Dóczi, 2011). Ez azt akarta sugallni, hogy hiába volt jelen keményen a sportban a vasmarkú rendszer, ettől függetlenül a szurkolók kulturális örökségéből fakadó identitását mégsem lehetett intézményes eszközökkel megváltoztatni vagy felülírni (Dóczi, 2011). A 70’-es évekre már egyértelműen megmutatkoztak azok a válságjelenségek, amelyek gyakorlatilag az ezutáni időszak honi sportját nagyban befolyásolták. Ennek a legföbb jeleiként a tömegsport és az utánpótlás-nevelés is egyre inkább a hazai sportélet peremére szorult, míg az élsport tömege mindinkább redukálódott. A kormányzat ezt a sport társadalmi irányításának a csődjével magyarázta, ezért 1973. április elsején megalkotta az új központi sportvezetést, az OTSH²-t. Mindez azonban az elsősorban egyre nagyobb mértékü finanszírozási gondok miatt lényegi változtatásokat már nem tudott eszközölni, így az új szervezet csupán még erőteljesebb ellenőrzés alá tudta vonni az állami és pártszervezeteket (Dóczi, 2011). Ez az intézkedés tehát nem tudta megakadályozni azt a már úton lévő folyamatot, hogy az élsport társadalmi bázisa egyre inkább zsugorodjon. Ezek az eredmények a különféle statisztikai kimutatásokban nem keltettek különösebb feltünést, hiszen a hivatalos eredményekben mindig nagy létszámról beszéltek és ezeket is tekintették mérvadónak. A valóságban azonban teljesen másképp volt: körülbelül 350-400 ezer sportoló váltogatta folyamatosan egymást, így ők jelentették a sportolók akkori egyedüli krémjét. Még mindig az 1970-es évekre tehető változás, hogy a sportegyesületek és a benne lévő szakosztályok is lassú leépülésnek, létszámbeli csökkenésnek indultak. Mindez az állami vállalatok egyre inkább romló gazdasági helyzetének eredményeképpen következett be. A legnagyobb gödörbe éppen a rendszerváltás idejére kerültek, 1990-ben ugyanis összesen 2716 egyesületet számláltak 5887 szakosztály kíséretében (Dóczi, 2011). A sport további veszteségeihez sorolandóak továbbá azok a korántsem elhanyagolható tényezők is, mint a sportegyesületi tagok és az igazolt versenyzők számának jelentős csökkenése, illetve a sportban dolgozó sportvezetők, szakemberek foglalkoztatottságának erőteljes leépítése (Dóczi, 2011).

Az 1980-ban Moszkvában megrendezett olimpiai játékok csak mérsékeltebb sikereket hoztak a magyar sportolók számára, így a 84'-es bojkottot követően ismételten lényeges legitimációs forrásoktól esett el a magyar (sport)politika. Az 1986-os mexikói labdarúgó világbajnokság kudarca ${ }^{3}$ azonban végképp betette a kaput: a sportrendszer müködését immáron a nyilvános fórumokon keresztül kezdték el kritizálni. Ezzel szemben azonban mégis érdekes, hogy mégsem voltak forradalmi jellegü megmozdulások, viszonylagos csend övezte a rendszerváltozást megelőző éveket. Ezek mellett új törekvések indultak be hazánkban, amelyek leginkább nemzetközi versenyek szervezésében mutatkoztak meg. Ilyennek számít például a Budapesti Atlétikai Verseny vagy a Mogyoródon a mai napig otthont adó Forma 1-es Magyar Nagydíj szervezése és lebonyolítása, amelyek nem mellékesen az ország arculat építésének is a szerves részét képezték (Laki és Nyerges, 2006; Dóczi, 2011). A 80'-as, 90'-es évek fordulóján végbement forradalmak eredményeképpen felszámolásra kerültek a totális rendszerek szerte Kelet-Közép-Európában, minekután egy olyan jellegü paradigmaváltás indult el ezekben a térségekben, amely kulturális, politikai és gazdasági alapokon nyugodott. Takács (1996) szerint ez a jelenség nemcsak a társadalmi szférák rendszereire, hanem a sportra is nagy hatással bírt (Vincze, 2008).

\footnotetext{
${ }^{2}$ OTSH=Országos Testnevelési és Sport Hivatal

${ }^{3}$ Az 1986-os Mexikói világbajnokságon a magyar futballválogatott csalódást keltően nem jutott tovább a csoportjából, csak a harmadik helyen végzett az utolsó Kanadát megelőzve. Egyetlen győzelmét a világbajnokságon éppen Kanada ellen érte el a Mezey György-féle válogatott.
} 
Ebben a fejezetben áttekintésre kerültek a magyar sportpolitikára jellemző legfőbb változások, események a II. világháborút követően egészen a rendszerváltozásig. A dolgozat ezt követő fejezetében a rendszerváltozás és az azt követő éveket járjuk körbe ugyanezen kérdéskör mentén.

\section{A magyar sport és politika kapcsolata a rendszerváltozás idejében és az azt követő években}

Viszonylag kevés azon empirikus kutatások száma, amely a rendszerváltás óra bekövetkezett sportbéli változásokkal foglalkozna. Ez azonban nem csak hazánkkal kapcsolatban van így, hanem minden olyan posztszocialista ország esetében, ahol a sport és a politika a miénkkel hasonló utakon ment keresztül. Ennek a legfőbb oka abban keresendö, hogy a társadalomtudósok számára kutathatóvá váltak olyan sporton kívüli területek is, amelyek eredményei a tudományos közvéleménynek jobban felkeltették a figyelmét, hiszen látványosabb lehetséges eredményeket hordoztak magukban (Dóczi, 2011).

Vincze (2008) szerint a rendszerváltás kezdete óta a sportot érintő és meghatározó folyamatok, változások a gazdasági, társadalmi és a politikai döntések, történések következményeiként határozhatók meg, tehát semmiképpen sem az átgondolt cselekedetek voltak a jellemzőek rájuk (Vincze, 2008). Ahogyan az előző fejezet végén olvashattuk, új indíttatású törekvések indultak be hazánkban, amelynek részeként nemzetközi versenyek lebonyolítását vállalták a magyar sport vezetői. A magyar sportot azonban az 1989/90-ben végbemenő rendszerváltozás kapcsán egyfajta transzformációs veszteség érte (Váczi, 2010). A 90'-es évek fordulóján bekövetkezett politikai és gazdasági rendszerváltás a sportegyesületek gazdasági helyzetére volt rendkívül negatív hatással. Ezáltal több sportszervezet saját bázisszervezetének az elvesztése végett a megszünésre kényszerült, mindemellett az utánpótlás-nevelést, illetve a magyar diák-és egyetemi sportot szintén rendkívüli veszteségek érték ebben az időszakban (Váczi, 2010). Ezeken túl fontos tényezőként jelentkezett a krónikus forráshiány, a jövedelmek beláthatatlan áramlása, illetve a sportsikerek nagyfokú elmaradása is (Berkes, 2008). Az biztosnak tünt, hogy a jóléti társadalmakban alkalmatos modell alkalmazhatatlan a posztszocialista országok rendszerében. A kelet-közép európai országoknak a piacgazdaságok felé kellett orientálódniuk, amely erősen megterhelő volt mind az államháztartásra, mind pedig az állampolgárokra nézve. Az ezzel járó finanszírozási takarékoskodás elsősorban a szociálpolitikai szolgáltatásokat érintette, mint például az egészségügy, a kultúra-és testkultúra, illetve az oktatás. Takács (1996) szerint ez azóta is visszafordíthatatlan és javíthatatlan károkat okozott ezeken az előbb felsorolt területeken (Vincze, 2008).

A rendszerváltás utáni években a sportban bekövetkező markáns változások rendre sporton kívüli társadalmi nyomás eredményeképpen következtek be. A gazdasági és jogi szférák megváltozásának egyik eredményeképpen az 1989. évi II. törvény került megalkotásra, amelyben többek között az új adótörvények, a magánosításról szóló törvények, illetve a régiek átalakítása miatt a sportban is változtatásokra volt szükség. A sportpolitikában a legnagyobb hangsúly a folyamatosságra hárult, ezzel igyekezték elkerülni a vészesen fenyegető összeomlást (Dóczi, 2011). Ezek a társadalmi-gazdasági müködésbeli változások negatív hatással bírtak mind a látványsportok, mind pedig a szabadidős sportpiac iránti kereslet majdnem minden tényezőjére. Ez az átmeneti időszak azt eredményezte, hogy a piacgazdaságra való átállás részeként a honi társadalom javarésze súlyos reáljövedelem csökkenést kényszerült elkönyvelni, így egyre kevesebb volt azoknak a száma, akik megengedhették maguknak a sportolást. Ezzel szoros összefüggésbe hozható az is, hogy ez a tényező nagyban hátráltatta a sportszolgáltatások piacán megjelenő fizetőképes kereslet 
megjelenését, felfutását. A sportban az imént említett tényezők tükrében így nem rendszerváltásról, hanem inkább leépülésről beszélhetünk (Váczi, 2010). A már említett társadalmi és gazdasági változások a sportélet résztvevőinek körében alig éreztették a hatásukat, mivel autonómiát élveztek a különböző sportegyesületek és sportszervezetek, ezért egyfajta szabadságérzet árasztotta el a sportolókat ezekben az időkben. Így az „újkapitalizmus” rohamos keletkezését és az ehhez szükséges gazdasági viszonyulás szükségességét alig érzékelték (Sárközy, 2009; Dóczi, 2011). A gazdaságban nagyobb tájékozottsággal rendelkezők tudhatták, hogy ha Magyarországon egyfajta erőltetett ütemü és időtartamú privatizációs folyamat indul be, akkor az új tulajdonosok drasztikusan le fogják építeni azokat a sportlétesítményeket és a velük járó sportfeladatokat, amelyek korábban az állami vállalatokba lettek mesterségesen beépítve (Dóczi, 2011). A sportvezetők nem vették észre azt, hogy ezek a privatizációs folyamatok gyakorlatilag elveszik tölük az anyagi javakat, éppen azért, mert a profitorientált tulajdonosok nem akarták átvenni a szocializmusból örökölt, mesterségesen beépített sportfeladatokat (Váczi, 2010). Szintén sokan sejtették a gazdaságban járatos személyek közül, hogy a multinacionális vállalatok mindaddig nem fognak a magyar sportban jelentősen szponzorálni, amíg vissza nem nyerik a befektetéseiket. Mindezt az elgondolást az akkor sokszor átláthatatlan tulajdonosi viszonyok és a gazdasági dekadencia következményei még inkább erősítették. A sportfinanszírozás területén, azon belül is az értelmezés terén így sokkal kevesebb előrehaladás történt, mint amit jósoltak az 1990-es évekre (Dóczi, 2011).

A honi civil társadalomban a szervezetek számát tekintve nagyméretü fejlődésről beszélhetünk az 1989-1995 közötti periódusban, de a sportra inkább egyfajta kettős folyamat volt ekkoriban a jellemző. A $70^{\prime}$-es, $80^{\prime}$-as évekre tehető leépülési folyamat az állami vállalatok válságával vette kezdetét, a rendszerváltozás után pedig ez még erőteljesebben azoknál a sportegyesületeknél jelentkezett, amelyek 1989 előtt alakultak meg. (Dóczi, 2011). Bukta (2003) szerint az egyesülési törvény hatására létszámban több új, kisebb egyesület is megalakult, amelyekre az alulról szerveződés volt a legjellemzőbb (Dóczi, 2011). Az új törvénynek az életbe lépése azonban felkészületlenül érte a sportszférát, emiatt a sportban nem úgy, mint a politikai, gazdasági szférákban - egyértelműen lassabban és szükebben ment végbe az átalakulás (Vincze, 2008). Az állami sportvezetés - szemben a szocialista korszakban tapasztaltakkal - nem tilthatta meg az újonnan megalakuló és beinduló, saját erőn alapuló sportágak és szövetségeik müködését (Dóczi, 2011). Váczi (2010) szerint a piacosodás egyik következményeként a 80 '-as évektől kezdődően hazánkban több sportág (pl.: labdarúgás, kosárlabda, tenisz, atlétika, stb.) kapcsán nagyfokú sikertelenség mutatkozott éppen amiatt, mert ezekben az elüzletiesedett sportágakban egyre nagyobb befektetésekre volt szükség a sikerek elérése érdekében. Ehhez hozzátevődik az, hogy maga a befektetői tőke is üzletet látott ezekben a sportágakban (Váczi, 2010). Ez a fokozatos piacosodás azonban a mai sportéletre szintén nagy hatással bírt: azokban a sportágokban, amelyekben hazánk hagyományosan sikeresnek tekinthető olyan erős nemzetközi verseny alakult ki, hogy a nemzetközileg elismert eredmények és sikerek elérése is egyre nehezebbé vált a sportolók számára (Váczi, 2010). Váczi (2010) szerint az állami sportfinanszírozás nem megfelelő müködésében, az elavult magyar sportszerkezetben és az abban tevékenykedök fundamentalista szemléletében szükséges keresni a legfőbb kiváltó okokat. Szerinte szükséges lenne néhány olyan tényezőt megváltoztatni, amely nagy befolyással lehetne erre a folyamatra. Ezek között említi többek között a stratégiai koncepciót, a menedzsmentszemléletet és a gyakorlati megvalósításra való hajlamot. A modern sportipar sikerességét a sportszakmában és a gazdaságban való sportiparági élet-és versenyképességben látja (Váczi, 2010). 
Érdemes áttekinteni a sport társadalmi környezetében végbemenő főbb változásokat is. A fogyasztói kapitalizmusban két réteget tudunk megkülönböztetni Sárközy (2009) szerint: az egyik rétegben a „gazdagok" sportjai, a másikban pedig a „szegények” népszerü sportjai jelennek meg. A fö különbség a két réteg között, hogy míg a „szegények” csoportjának legnépszerübb sportágaiban a teljes leépítés figyelhető meg, addig a másik oldalon tenisz-és golfpályák szaporodnak sorra, teret nyernek a lovaspóló és a squash sportágak, illetve bowlingközpontok is egyre gyakrabban létesülnek (Sárközy, 2009; Dóczi, 2011). Az állami támogatások rendszerében a felépítés markánsan nem változott a rendszerváltozás óta, még mindig az élsport-és nyári olimpia centrikusság maradt a középpontban a szervezetcentrikusság mellett. Ha az állami költségvetés radikális módon változtatna és átalakítana, akkor annak minden bizonnyal az élsport lenne az elsődleges áldozata, amely azonban minden erejével és a már meglévő, erős kapcsolatrendszerének a segítségével igyekezne védeni az eddig megszerzett pozícióit (Dóczi, 2011). Hiába volt tehát jelentős szemléletbeli változás a rendszerváltozás utáni kormányok szemléletmódjaiban, a sportpolitika szférájában mégis több azonosságot is fel tudunk fedezni a szocialista időszakra jellemző sportpolitikával. Dóczi (2011) szerint a rendszerváltozás utáni kormányok deklarált céljai között jelentek meg a sport egységének, egyenlöségének megteremtése és fenntartása, a sporttehetségek felkarolása és támogatása, valamint a sport általi egészségfejlesztés, ezek azonban korántsem valósultak meg következetes módon. Az 1990 és 2008 között kormányon lévő pártok túlzott mértékben is priorizálták az élsportot a nem élsportnak számító sportágakkal szemben, mindemellett az élsportolók sikereiből igyekeztek politikai elönyöket megszerezni. Tehát hiába volt gyökeresen más az ideológiai, politikai kulturális és a stílusbeli meghatározottság, mindkét korszak politikája egyezik abban a tekintetben, hogy a legitimitásukat a magyar sportsikerekkel igyekezték megerősíteni (Bakonyi, 2007; Dóczi, 2011).

Összegzésként kíváncsiak voltunk az előbb áttekintett szakirodalmak tükrében, hogy a sportipar müködési modellje miként változott az államszocializmus idejéből kiindulva egészen a rendszerváltás utáni időszakba kitekintve. András (2004) eredményeként a sportipar müködési modellje esetében két fő ágens különíthető el egymástól: az egyik az állami, a másik az üzleti modell (1. táblázat).

1. táblázat: Az állami és az üzleti alapú sportmodell összehasonlítása (forrás: András, 2004, 10. o.)

\begin{tabular}{|c|c|c|}
\hline Jellemzők & Állami modell & Üzleti modell \\
\hline Finanszírozás forrása & Állami bevételek & Üzleti bevételek \\
\hline $\begin{array}{c}\text { Költségvetési korlát } \\
\text { szerepe }\end{array}$ & Puha költségvetési korlát & Kemény költségvetési korlát \\
\hline Tulajdonos jellemzője & Nincs valós tulajdonos & Valós tulajdonos megléte \\
\hline Müködési kerete & $\begin{array}{c}\text { Non-profit: } \\
\text { Uársadalmi, egyesületi forma }\end{array}$ & $\begin{array}{c}\text { Üzleti: } \\
\text { gazdasági társasági forma }\end{array}$ \\
\hline A sport jellemzó szerepe & $\begin{array}{c}\text { Politikai rendszer legitimálása, } \\
\text { közhangulat javítása }\end{array}$ & $\begin{array}{c}\text { Szolgáltatás a szórakoztató } \\
\text { iparág részterületeként }\end{array}$ \\
\hline
\end{tabular}

Az államszocializmus idején az állami sportmodell a kelet-európai országok esetében volt a leginkább jellemző, így hazánk is ebbe tartozott. A legfőbb ismérveként az említhető, hogy az állam komoly hatással és befolyással bírt a különböző sportágak irányításába, 
finanszírozásába és müködésébe egyaránt, ezáltal a bevételek állami forrásból valók voltak (Váczi, 2010). Üzleti alapú müködésröl akkor tudunk beszélni, ha a sportágak müködésében keletkező kiadások fedezetét azok a bevételek biztosítják, amelyeket a piacról szereznek meg. Tehát ez a modell mindenképpen piaci meglétet és fogyasztói jelenlétet is feltételez egyben (András, 2004).

Ha megvizsgáljuk az állami és az üzleti alapú sportmodell müködési elemeit, akkor lényegi különbségeket fedezhetünk fel bennük. Például a tulajdonos kérdésében látható, hogy míg az állami modellben nincs valós tulajdonos (ami maga az állam), addig a rendszerváltozás utáni években elötérbe került üzleti modellben már van. A markáns különbség még tetten érhető a müködési keretekben is, ugyanis az állami modellben non-profit, társadalmi egyesületi forma volt a jellemző, az üzleti modellben pedig gazdasági társasági formaként müködtek és müködnek az egyesületek. Ami még jelentős különbség, hogy míg a korábbi modellben a sport a politikai rendszer legitimálásaként volt jelen elsősorban, addig az üzleti modellben egyfajta szolgáltatásként funkcionál a szórakoztató iparág részterületeként (András, 2004). Érdemes még áttekinteni emellett az üzleti alapú modell müködésének feltételeit is a labdarúgás példáján keresztül vizsgálódva: nagyon fontos, hogy a labdarúgás eladhatóvá váljon a sportfogyasztó részére, ami azt jelenti, hogy a jegy-és bérletbevétel feltételeit a fizetőképes kereslet alapján határozzák meg. Mindemellett szintén lényeges, hogy a labdarúgásba anyagi forrást fektetett szponzorok számára a futball által elérendő célcsoportjuk gazdaságilag minél inkább értékes legyen számukra. A futballvállalatok további bevételeket tudnak szerezni a játékoseladásokból, de ezeknek a nagyságát egyaránt a külső (pl.: az adott bajnokság színvonala, válogatottjának eredményei, stb.) és a belső (a futballvállalatnál létrejövő utánpótlás-nevelési munka milyensége, a játékos-kiválasztási részleg eredményes működése, a klub földrajzi elhelyezkedése, mérete, stb.) tényezők együttesei adják (András, 2004).

Ebben a fejezetben áttekintésre kerültek azok a lényegi elemek és történések, amelyek nagyban befolyásolták a rendszerváltás környéki és az azutáni időszak sportpolitikai nézeteit, főbb változásait. A következő szerkezeti egységben szeretnénk a sport egyik szükebb rétegeként a labdarúgás sportágával kapcsolatos fóbb sportpolitikai változásait is áttekinteni 1945-től kezdődően egészen a napjainkig. Célunk még, hogy a labdarúgáson belül a labdarúgó akadémiák jelenségére is rámutassunk, müködésüket a sportpolitikai folyamatokban elhelyezzük.

\section{A labdarúgás sportpolitikával kapcsolatos helyzete, álláspontja 1945-től a rendszerváltásig terjedően}

A II. világháború utáni években a többpártrendszer idején viszonylag nyugodtan, önállóan müködhettek a különböző labdarúgó-szakosztályok, azonban a szocialisták hatalomra kerülésük után teljesen átszervezték a sport rendszerét (Vincze, 2008). Kezdetben a labdarúgás elsősorban a társadalmi hasznossága miatt kaphatott politikai figyelmet, leginkább jellem-és közösségformáló szereplöként, illetve az egészségre gyakorolt kedvező hatásként tekintettek rá a politikai gondolkodásban (Berkes, 2008; Kozma-Nagy 2002). A szocialista rendszerben a labdarúgás által igyekeztek a politikai vezetők a politikai legitimációjukat, a közhangulatot és az akkor megtört nemzeti hovatartozásukat egyaránt erősíteni. A gazdasági müködés tartópilléreként a sportegyesületek funkcionáltak, amelyeknek az elsődleges céljuk a minél több sportsiker elérése volt. Mivel ezek a sikerek közcélt szolgáltak, ezért állami finanszírozásba részesülhettek (Berkes 2008; Kozma-Nagy, 2002). Ekkoriban a legnagyobb 
futballkluboknak számító hazai egyesületek finanszírozását tekintve jelentős szereppel egyegy állami vállalat vagy minisztérium bírt. Így történhetett meg az is, hogy például a Ferencváros esetében a mezőgazdasági minisztérium, az Újpesti Dózsa mögött a belügyminisztérium, míg a Győri ETO müködésének hátterében a Rába állt (Kozma-Nagy, 2002). A hatalomnak ezzel a legfőbb célja az volt, hogy megfosztják a klubokat a szurkolóiktól, anyagi bázisuktól és legfőbb támogatóiktól. Ebben az időszakban kezdődtek el a stadionépítések is hazánkban, ennek egyik fö állomásaként 1953-ban felavatásra került a Népstadion, amely 100 000-es befogadóképességgel bírt. Emellett számos első osztályú klub labdarúgópályája szintén felújításra került (Vincze, 2008). Ezekkel összefüggésben egyre több és több ember tekintette úgy, hogy a sport sikere és támogatása egyaránt a „nép érdeke”, ebben a sportszervezetek és a sportolók feladataként a sportsikerek elérése jelent meg, azonban a gazdasági háttérmüködés egyértelmüen az állam kezében volt. Ennek talán a legékesebb példája maga az Aranycsapatként ${ }^{4}$ elhíresült nemzeti labdarúgó tizenegyünk volt, amely az ötvenes években világraszóló sikereket aratott a nemzetközi színtereken, ismertséget és elismertséget is szerezvén ezzel Magyarországnak. A nép szinte egy emberként állt be a csapat, illetve a sportág mögé, ők pedig sorra szállították a nagyobbnál nagyobb dicsőséges diadalokat a nemzetnek (Kozma-Nagy, 2002). Az Aranycsapat ezáltal a politikai belső vezetés egyik kedvencévé és büszkeségévé nőtte ki magát, egyúttal hivatkozási alappá válva ezzel. A sportba ettől kezdve rendkívül komoly állami pénzt invesztáltak, az élsportolók pedig egyfajta kiváltságos szerepkörrel bírtak (Vincze, 2008). Mivel azonban a honi labdarúgás első jelentősebb sikerei klub-és válogatott szinten is a tervgazdálkodási időszakra estek, így a sportág könnyen a regnáló gazdasági-társadalmi rendszer ideológiai csapdájába tudott kerülni (Berkes, 2008). A sport, ezen belül pedig a labdarúgás a politikai rendszer adujává vált, éppen ezért mindent megtettek annak érdekében, hogy továbbra is fenntartsák a sportolóik ezt a sikerességet. Ennek érdekében a politikai vezetés minden támogatást megadott, viszont a döntések jogát saját maguknak tartották fent. Ennek a korszaknak a sportvezetői így a politika által kiválasztott és megnevezett személyek voltak, akik teljes mértékben azonosultak a rendszerrel és megfeleltek az elöírt elvárásoknak (Vincze, 2008). 1956-ban újabb mérföldkőhöz érkezett a honi futballrendszerünk, ekkor ugyanis a forradalom hatására szétesett az Aranycsapat, sokan disszidálni kényszerültek, a labdarúgás rendszerét pedig teljes átalakítás alá vetették. Elérkezett a szocializmus Kádár-korszaka, amelyben elindult a labdarúgás önállósodási folyamata. A Puskás-korszak megszünését feledtetve a hatalom visszaadta a klubok eredeti színeit és neveit, emellett a rendszer már csak közvetve avatkozott bele a labdarúgásba, amennyiben nagy szükségességét érezte. A Kádár-korszak további jellemzőjeként a vidéki egyesületek térnyerése említhető meg, amely során a Rába ETO megnyerte az 1982-83-as magyar bajnokságot, a Videoton pedig 1980-ban a második helyet szerezte meg az UEFA Kupa küzdelmei során. Mindezen eredmények azt jelentették, hogy a helyi szervezetek is elindultak a megerösödés útján (Vincze, 2008).

Ebben a fejezetben áttekintésre kerültek azok legfontosabb sportpolitikai megmozdulások, változások, amelyek a szocializmus korában jellemezték a honi labdarúgást a II. világégéstől kezdődően egészen a rendszerváltozásig. De vajon a rendszerváltozás milyen hatással volt a magyar labdarúgás politikájára? Beszélhetünk-e a labdarúgás sportpolitikai aspektusában paradigmaváltásról? Ha igen, akkor ez milyen hatással volt ez a rendszerváltozás utáni évekre? A következő alfejezetben ezekre a kérdésekre keressük a választ.

\footnotetext{
${ }^{4}$ Az Aranycsapat nemzetünk 50'-es évekbeli sikerválogatottja volt, amely az 1954-es világbajnokság döntőjében elszenvedett veresége előtt mindösszesen egy vereséget számlálhatott az öt év alatt. A legnagyobb játékosok között kell említeni például Puskás Ferenc, Hidegkúti Nándor, Kocsis Sándor és Czibor Zoltán nevét is. Az Aranycsapat egyik legnagyobb diadalaként első ízben győzte le hazai pályán az angol válogatottat 1953-ban, a Wembley-stadionban (Vincze, 2008)
} 


\section{A rendszerváltás és az azt követő évek labdarúgáspolitikája}

Ennek az említett lehetséges paradigmaváltásnak az egyik meghatározó előzményének tekinthető, hogy a szocialista rendszerrel kapcsolatos problémák hosszú ideig megválaszolatlanok maradtak a sportban érdekeltek körében. Ennek a fö okaiként az állami támogatás és a sportsikerek nagyfokú megrendülése említhető, amelyek szinte egymással egyidejüleg következtek be (Kozma-Nagy, 2002). Egészen 2016-ig 1986-ban volt utoljára nagy labdarúgó világesemény résztvevője nemzetünk válogatottja, akkor is csupa negatív élménnyel térhettek haza labdarúgóink. Sokak szerint a mexikói világbajnokságon a Szovjetuniótól elszenvedett 6-0-s vereség szintén a hanyatlás egyik első komoly állomásaként tekinthető (Kozma-Nagy, 2002). A politikai rendszerváltozás önmagában rendkívül éles változásokat hozott a társadalom életének legtöbb területén. A sportban - mint egyfajta társadalmi alrendszerben - csak idővel kezdődtek el ezek a rendszerváltozás által kiváltott átalakulások. A rendszerváltáskor a társadalom, a politika és a sportszakma is úgy tekintette, hogy a sporttársadalom képes lesz megteremteni a működőképes demokráciát (Bakonyi, 2004; Berkes, 2008). Viszont felmerültek ezzel kapcsolatban olyan kérdések is, amelyek nagyfokú bizonytalanságérzetet hordoztak magukban. Kérdésként merültek fel többek között, hogy vajon az állam magára hagyhatja-e a sportszférát és ezen belül a labdarúgást a kialakulóban lévő piacgazdasági feltételekben? Vajon lépést tudnak-e tartani az éppen végbemenő politika-gazdasági és egyúttal társadalmi átalakulással? A válaszok elég sok bizonytalanságot, kétkedést hordoztak magukban, abban viszont biztosak voltak, hogy az előző rendszer maradványait, megmaradt szegmenseit nem lehet egyik pillanatról a másikra megváltoztatni, a sportszféra pedig önmagában nem lett volna képes megfelelni a körülötte nagyban megváltozott körülményeknek (Kozma-Nagy, 2002).

A váltást követően hazánk sportja - és egyúttal a labdarúgása is - a nyugati minták követésének irányába indult. Emellett lényeges változás volt még, hogy kényszerüségből a finanszírozási és az irányítási szerkezete is megváltozott a futballnak. Az ennek a hátterében meghúzódó piacgazdaságnak a sportra való hatása teljesen más megközelítési módokat igényelt, mint az előző rendszeré. Ez újabb kérdéseket vetett fel, és egyúttal a paradigmatikus alapok újraértelmezése is elkezdődött. A megszületőben lévő új paradigma középpontjában immáron az üzleti hasznosság motívuma került, amely a szocializmusban ismeretes társadalmi hasznosság paradigmájának az utódjaként tekinthető (Kozma-Nagy, 2002). A szakemberek a problémák tudatában afelé a megoldási lehetőség irányába hajlottak, hogy egy teljesen más, az eddigiektől különböző logika alapján működtethető rendszert szükséges kiépíteni. Ez olyan átértelmezéseket tett szükségessé, mint például a futball társadalmigazdasági létjogosultságának a kérdése. Ez azonban a meglévő paradigma mélyrehatóbb átalakítását vonta maga után (Kozma-Nagy, 2002). Az egyik legfőbb változásként 1989 után a labdarúgásnak váltania kellett az állami támogatásról a piaci alapú támogatásra, amely folyamat nagyon lassan és rendkívül sok ellentmondással tarkítva telt (Vincze, 2008). Ez azzal is járt, hogy az inkább puha költségvetési korlátokat ismert sportvezetők eleinte nehezen találták magukat a piacgazdasági viszonyok rengetegében (Berkes, 2008). Krausz (2008) szerint a magyar futball a piacra nyitás után óriási veszteségeket szenvedett. A legtöbb magyar labdarúgóklub azzal próbálta meg fenntartani magát, hogy a saját szempontjukból kedvezőtlen feltételek mellett is eladták a legjobb játékosaikat külföldre úgy, hogy nekik nem volt lehetőségük külföldről játékosokat csábítaniuk a csapataikba. Ennek a következménye mára az lett, hogy rengeteg honi labdarúgónk játszik jelenleg a különböző külföldi bajnokságokban, amely nagy vérveszteséggel jár manapság is a magyar élvonal számára (Krausz, 2008). 
Az üzleti paradigma előtérbe kerülése és hatalomátvétele 1997 és 1998 közé illeszthető a honi labdarúgásunkat tekintve. Ehhez kiindulópont volt a Jugoszlávia ellen elszenvedett kettős vereség is, amely után a felállított munkabizottság javaslatára törvénymódosításra került sor. Az akkor hatályban lévő 1996. évi LXIV törvény került módosításra úgy, hogy csak gazdasági társaságként indulhattak a csapatok a hivatásos bajnokságokban (KozmaNagy, 2002). Az 1998-as évben a futball tisztán üzleti alapon kezdődő müködése új lehetőségként jelent meg a sportközvéleményben. Ha a kormánypártokat vesszük górcső alá, akkor elmondhatjuk, hogy az üzleti paradigma térnyerése és túlsúlyba kerülése a FIDESZ 1998-as választási programjában, majd az aztán megalakuló koalíciós kormány programjában és szakmai anyagaiban jelentek meg első ízben. A programalkotók legfőbb elképzelései szerint a labdarúgásnak látványsportként volt szükséges müködnie a jövőre tekintve, olyan szolgáltatásként funkcionálva, amelyben a labdarúgás iránti keresletet kiegészítve profitot is biztosít az iparág részére. A program szerint az állam számára a labdarúgás hosszú távon tekintve a bevételi oldalon jelenne meg a kiadásival oldallal szemben (Kozma-Nagy, 2002). Ugyanakkor ez a fajta vélekedés szintén erős óvatosságra intett, hiszen az effajta modell még a legjobban és a legbiztosabban müködő nyugat-európai országokban sem volt mindenhol üzemképes. A kisebb, kevésbé ismert vagy elismert csapatok nem mindig tudják megteremteni maguknak azt a nyereséget, amely a hosszú távú müködésük alapjául szolgálhatna. Ráadásul - cseppet sem mellékesen - a futball-iparág müködését a médiapiaci bizonytalanságok is erőteljesen kétségbe vonják (Kozma-Nagy, 2002).

Ami tehát összegzésként megállapítható, hogy a paradigmaváltás nem ment végbe teljesen abban az értelemben, hogy a szocialista rendszerre jellemző társadalmi hasznosság paradigmáját felváltotta volna teljes egészében az üzleti hasznosság paradigmája. Ahogyan ez látható, mindkettő paradigma jelen van a sportpolitikai koncepciókban, így lényegében egymás mellett müködnek szorosan (Kozma-Nagy, 2002).

\section{A jelen vizsgálata: a labdarúgó akadémiák megjelenése, térnyerése és politikája}

Ebben az alfejezetben kitekintést teszünk a magyar labdarúgás utánpótlásnevelésén belül müködő labdarúgó akadémiák sportpolitikai helyzetére.

András (2003) esettanulmányon alapuló kutatása szerint hiába történt meg honi futballunkban a piacosítás, a futballtársaságok jelenlegi müködését mégsem az üzleti alapon nyugvó üzletmenet határozza meg, hanem a tulajdonosok által máshol kitermelt pénzek folyamatos futballba való forgatása, a törvényi kiskapuk kihasználása vagy éppen a köztartozások magántartozásként való átkonvertálása (András, 2003; Berkes, 2008). Szegedi (2003) szerint szintén alapvető probléma, hogy a labdarúgás berkein belül eleddig nem jelent még meg az a magánszféra, amely hosszú távon is képes üzletet és befektetés látni a sportágon belül. Éppen ezért az állami támogatásoknak rendkívül kiemelt szerepük van, olyannyira, hogy több egyesület esetében egyedüli bevételnek számítanak (Vincze, 2008). Vincze (2008) szerint a sport egyszerủen képtelen állami segítség nélkül müködni, amelyre jól rámutat az is, hogy manapság mely sportágakban számítunk a legsikeresebbeknek. Azokban a klasszikus sportágakban, látványsportokban, ahol a nagyobb pénzek forognak (pl.: kosárlabda, tenisz vagy labdarúgás) kevésbé vagyunk eredményesek és kevesebbszer jutunk az élmezőny közelébe. Azokban a sportágakban azonban, amelyek kevésbé preferáltak (pl.: kajak-kenu, öttusa) folyamatosan szállítjuk a nemzetközi sikereket, emellett a nagyobb sportrendezvényeken, mint például az olimpiákon vagy a különböző világ-és Európabajnokságokon rendre a világ élmezőnyébe végeznek sportolóink (Vincze, 2008). Ami manapság további problémát okoz, hogy a honi labdarúgás alacsony színvonala, eredménytelensége miatt a nézők más sportágak és szórakozási lehetőségek felé kezdtek el 
nyitni és orientálódni. Ennek következményeként a labdarúgás népszerüsége és gazdasági ereje egyaránt erösen lecsökkent (Vincze, 2008).

Talán ennek a labdarúgással kapcsolatos kiábrándultságnak és népszerüségvesztésnek köszönhetően indulhatott be Magyarországon az elsősorban utánpótlás-nevelés előmozdítását megcélzó labdarúgó akadémiai rendszer egyre nagyobb arányú térnyerése hazánkban. A nyugat-európai mintákon szerveződő akadémiai rendszer azonban nem volt teljesen ismeretlen sem a magyar, sem pedig a kelet-európai sporttörténetben. Az NDK-típusú sportiskolák kísértetiesen hasonló metódusokkal müködtek, mint a mai futballakadémiák. Ott ugyanis szintén megjelent a bentlakásos rendszer, illetve a munkaerö-szakképzés is. Ezek a tervgazdaság éveiben aktívan müködtek hazánkban (Dénes, 2015). 2001-ben Agárdon, Várszegi Gábor indíttatásából és finanszírozásából megalakult az első honi labdarúgó akadémia, amely a mai napig az Aranycsapat egykori kiváló szélsőjének a nevét, Sándor Károlyét viseli.

Ezek után szinte gombaszámra alakultak meg az újabb és újabb labdarúgó akadémiák, így manapság már közel 15-öt számlálhatunk. Ugyanakkor - ami a labdarúgó akadémiai rendszer egyfajta kritikájaként is felfogható - az egyes objektív mércékkel mérhető mutatók és a különböző klub vagy nemzeti rangsorok (mint például a magyar labdarúgó válogatott sorozatos elmaradása az egyes világtornáktól vagy éppen a honi klubcsapataink javarészt eredménytelen szereplése a nemzetközi futballban) mind azt mutatják, hogy korántsem talált még magára nemzetünk futballja (Orosz, 2009). Ezen problémák alapjául szolgál továbbá az is, hogy az utánpótlás-nevelés kérdésköre eddig még nem teljesen megoldott hazánk labdarúgásában, mindemellett ez hiányosságként mutatkozik a sporttudományos élet szféráin belül is (Csáki és mtsai, 2013). Dénes (2015) szerint a labdarúgó akadémiák megjelenésének a legföbb céljai közé sorolhatók a hivatásos, profi labdarúgók nevelése, emellett a futballipar utánpótlásának szakképzése, biztosítása. Az akadémiák üzleti modelljének az alapja, hogy a nyugat-európai országok díjaihoz képest olcsóbbak a fiatalok képzésének a költségei, azonban ezzel szemben a nemzetközi futballpiac játékosainak az ára sokkalta magasabbak, mint a magyar árszint (Dénes, 2015). A számítások szerint egy-egy labdarúgó akadémia éves müködési költsége 80-130 millió forint közé esik, amely kiadást akár egy-egy nagyobb értékü játékos eladásával kényelmesen kompenzálhatnak és megtermelhetnek az utánpótlás bázisok (Dénes, 2015). Szabados (2008) megjegyzi tanulmányában, hogy a transzferstratégia minden magyar klub esetében megjelenik, amelynek lényege, hogy a klubok minél több játékosukat igyekeznek minél magasabb áron eladni külföldi egyesületekbe. Ezt segíti az is, hogy a nemzetközi árak sokkal magasabbak a magyar viszonylatokhoz képest, így egy-egy játékos eladása egy klub esetében akár a teljes éves költségvetést is fedezheti (Szabados, 2008). A labdarúgó akadémiák széleskörü elterjedése egyértelmủen kontextusba hozható a jelenleg regnáló kormány egyik politikai célzatú intézkedésével, hiszen az akadémiák sorozatos megalakulása és bázisuk bővülése éppen erre az időszakra tehető. A politikai célzat azonban nem teljesen ismert, viszont éppen a hatalmas infrastrukturális fejlesztések és az ebbe fektetett tőkék okán egyre több sportban és sporton kívül tevékenykedő ellenszenvét váltja ki. Mindez azzal is párosul, hogy hiába rendelkezik immáron közel 17 éves múlttal a magyar labdarúgó akadémiai rendszer, számottevő eredményt nem sikerült elérni azóta sem, így lényegi elörelépésröl nem tudunk beszélni a jelenségüket illetően.

A magyar labdarúgó akadémiai rendszer kialakítása tehát egyfelől mindenképpen lehetőség arra, hogy már gyermekkortól kezdve a fiatal labdarúgók professzionális sportági szakképzésben részesülhessenek, ezáltal olyan alapokra tegyenek szert az akadémia képzésen belül, amely valóban minőségi és eredménybeli javulást hozhat a labdarúgásunkban. Másfelöl azonban több kérdés is felvetődik a laikusok és a sportban járatosak között egyaránt velük kapcsolatban, éppen ezért a labdarúgó akadémiákkal kapcsolatban a hazai közvélemény 
erősen megosztottnak tekinthető. Ez a megosztottság részint annak köszönhető, hogy mind a sportszakmabeliek, mind pedig a laikusok erösen hiányolják azokat a szakmai sikereket, eredményeket, amelyeket a magyar labdarúgásnak kellene folyamatosan produkálnia ilyen szintü háttér mellett. Ennek az elvárt eredményességnek nélkülözhetetlen elemei a közel 17 éves múlttal rendelkező, a magyar labdarúgás utánpótlás-fejlesztésének érdekében létrehozott labdarúgó akadémiák is. További kérdéseket vetnek fel az ezen intézményekkel erősen kapcsolatba hozható, nagy volumenü infrastrukturális fejlesztések és a komoly pénzek, melyek köz- és magánforrásokból egyaránt megjelennek a müködésben. Amíg azonban elmaradnak a sikerek, addig mindig lesznek kétkedők az akadémiákat és az akadémiai rendszert illetően. Talán a 2016-os Európa-bajnokságra való kijutás és eredményes helytállás enyhített valamelyest a negatív hangokon, de mint utóbb kiderült, ez az eredmény is inkább időszakos tüzoltásként volt jelen, mintsem ténylegesen is a futballunk magára találásáról szólt volna.

\section{Konklúziók}

Jelen elméleti jellegü publikációnkban áttekintésre kerültek a sportpolitika legfőbb intézkedései, jellemzői a II. világháborútól kezdődően egészen a rendszerváltásig és napjainkig terjedően.

A tanulmány első fő egységében a magyar sport helyzetét tekintettük át általánosságban a sportpolitika vetületében, ezen belül két alegységben tárgyaltuk a rendszerváltásig, illetve a rendszerváltás és az azt követő időszakok föbb jellemzőit. A dolgozat második fö egységében már a sport egyik szükebb területeként a labdarúgással kapcsolatos legfontosabb sportpolitikai változásokat, intézkedéseket tekintettük át. Ezen fö fejezet első alegységében a II. világháborútól kezdődően egészen a rendszerváltozásig vizsgáltuk meg a labdarúgás sportpolitikai helyzetét, a második alegységben a rendszerváltozás és az azt követő éveket elemeztük, majd a harmadik alegységben a jelen idők és a labdarúgó akadémiák jelenségeit vizsgáltuk ugyanezen aspektusból.

Eredményeink alapján elmondható, hogy a magyar sportrendszert általánosságban tekintve a szocialista korszakban inkább a széles tömegek megmozgatása volt a legfőbb cél a politikai vezetés részéről. Ezek mellett fontos céljuk volt még a legitimáció megszerzése és megtartása, ezért az élsportot helyezték előtérbe, amely miatt a tömegsport indult hanyatlásnak. A rezsim ugyan minden támogatást megadott az általuk preferált sportágaknak, a háttérben mégis minden intézkedés mögött a politikai vezetés állt. A rendszerváltás a sport területén vontatottabban ment végbe, a beindult piacosodási folyamat miatt pedig több sportág is eredménytelenné vált. Váczi (2010) szerint így inkább leépülésről, mintsem rendszerváltásról beszélhetünk a magyar sportrendszert tekintve (Váczi, 2010).

A labdarúgás kapcsán a szocializmus egyik fö sportbéli bástyája az Aranycsapat lett, amely mögé teljes mellszélességgel állt a politikai vezetés, nyilván ezzel a rendszer hivatkozási alapjává is téve a válogatottat. Az 1956-os forradalom után némileg puhult az addig kemény kézzel bánó szocialista rezsim, az Aranycsapat elvesztését pedig azzal igyekezték kompenzálni, hogy a labdarúgóegyesületek részére visszaadták az elvett klubszíneket és neveket. A rendszerváltást követően hazánk labdarúgása a nyugati minták követésének irányába indult. Mindeközben megszületöben volt az új paradigma, amely az addigi társadalmi hasznosság paradigmáját igyekezett leváltani és az üzleti hasznosság útjára terelni. Mint ahogyan azonban a szakirodalmak alapján kiderült: ténylegesen mégsem ment végbe a teljes paradigmaváltás, hiszen a mostani müködésben továbbra is megfigyelhetők a szocializmusra jellemző sportpolitikai jellemzők.

A labdarúgó akadémiák kapcsán erősen megosztott közvéleményről beszélhetünk. A rendszer közel 17 éves múltra tekint vissza és láthatóan a regnáló kormányvezetés egyik 
politikai döntésének eredményeképpen szaporodik folyamatosan a létszámuk. Az akadémiai rendszer a sok hasznossága mellett veszélyeket is rejt magában, de ami a legégetőbb probléma, hogy a közel 17 éves müködésük után sem tudták még teljes mértékben igazolni a létjogosultságukat éppen azért, mert nagyfokú bizonytalanság övezi egyaránt a müködésüket és az eredményességüket.

\section{IRODALOM}

András, K. (2003). Üzleti elemek a sportban, a labdarúgás példáján. Doktori értekezés. Budapest: Budapesti Közgazdaságtudományi és Államigazgatási Egyetem Gazdálkodástani Ph.D. Program, Vállalatgazdaságtan Tanszék.

András, K. (2004). A hivatalos labdarúgás piacai. 53. számú mühelytanulmány. Budapest: Budapesti Közgazdaságtudományi és Államigazgatási Egyetem, Vállalatgazdaságtan Tanszék.

Bakonyi, T. (2007). Állam, civil társadalom, sport. Budapest: Kossuth.

Bakonyi, T. (2004). Civil álom és politikus állam - adalékok a civil sportszervezetek státuszának legújabb kori politikatörténetéhez Magyarországon. Budapest: Doktori értekezés.

Berkes, P. (2008). Marketingorientációs tényezők a honi professzionális labdarúgás szponzorációs piacának tükrében. Doktori értekezés. Budapest: Nevelés-és Sporttudományi Doktori Iskola.

Bukta, Zs. (2003). A sport civil szférája Magyarországon. Civil Szemle 3, 59-77.

Csáki, I., Bognár, J., Trzaskoma-Bicsérdy, G., Zalai, D., Mór, O., Révész, L. \& Géczi, G. (2013). A sportágválasztás, a tehetséggondozás és az edző sportoló kapcsolat vizsgálata elit utánpótláskorú labdarúgók körében. Magyar Sporttudományi Szemle, 14. 55. 9- 16.

Dénes, F. (2015). Sportközgazdaságtan. Debrecen: Campus Kiadó.

Dóczi, T. (2011). Rendszerváltás, globalizáció és nemzeti identitás a sportban a XXI. század kezdetén Magyarországon. Doktori értekezés. Budapest: Semmelweis Egyetem, Sporttudományi Doktori Iskola, Sport-és Társadalomtudományi Program.

Hadas, M. \& Karády V. (1995). Futball és társadalmi identitás. Replika 17-18. pp. 89-119.

Kozma, M. \& Nagy, T. (2002). Nagy pénz - kis foci avagy a paradigmaváltás lehetösége a magyar labdarúgásban. Mühelytanulmány. Budapest: Budapesti Közgazdaságtudományi és Államigazgatási Egyetem, Vállalatgazdaságtan Tanszék.

Krausz, T. (2008). Bevezetés - A magyar futball „szétglobalizálása”. In A játék hatalma: Futball-pénz-politika. Kelet-európai tanulmányok II. (Krausz T. \& Mitrovics M. szerk.).

Budapest: L’Harmattan Kiadó, ELTE BTK Kelet-Európa története tanszék pp. 11-28.

Laki L. \& Nyerges M. (2006). Politika és élsport. Társadalomkutatás 24, pp. 493-513.

Orosz, R. (2009). A labdarúgó tehetség kibontakozását befolyásoló pszichológiai tényezök vizsgálata. Doktori értekezés. Debrecen: Debreceni Egyetem Humán Tudományok Doktori Iskola.

Orosz, R., Mező, F. (2015). Psychological Factors in the Development of Football-Talent from the Perspective of an Integrative Sport-Talent Model. Journal for the Education of Gifted Young Scientists 1: pp. 58-76.

Rábai, D. (2016): Labdarúgó akadémia mint oktatási, nevelési környezet. Szakdolgozat, Debrecen: Debreceni Egyetem Neveléstudományok Intézete, Kézirat.

Sárközy, T. (2009). Amit nem láttunk, de ma már látszik a sportban. Mozgó Világ 35(1).

Szabados, G. (2008). A labdarúgóklubok stratégiái. In A játék hatalma: Futball-pénz-politika. Kelet-európai tanulmányok II. (Krausz T. \& Mitrovics M. szerk.) Budapest: L’Harmattan Kiadó, ELTE BTK Kelet-Európa története tanszék, pp. 58-76. 
Szegedi, P. (2003). Az utánpótlás-nevelés a magyar labdarúgás struktúrájában. Századvég, Budapest.

Takács, F. (1996). Testkultúránk aktuális szociológiai problémái a rendszerváltozás után. In: Földesiné, Sz. Gy. (szerk.) A magyar sport szellemi körképe 1990-1995. Budapest: OTSHMOB, pp. 53-67.

Újhelyi, J. (1949). Népi demokrácia és sport. Budapest: OSH.

Váczi, J. (2010). Az állami sportfinanszírozás új útjai. Doktori értekezés. Budapest: Nevelésés Sporttudományi Doktori Iskola.

Vincze G. (2008). Az 1989-90-es politikai rendszerváltás hatása a labdarúgó utánpótlás nevelésre. Doktori értekezés. Budapest: Semmelweis Egyetem, Nevelés-és Sporttudományi Doktori Iskola, Sport-, Nevelés- és Társadalomtudományi Program. 